\title{
Influence of phosphoric anions on oxygen reduction reaction activity of platinum, and strategies to inhibit phosphoric anion adsorption
}

\author{
Yuping Li a,b, Luhua Jiang a,*, Suli Wang a, Gongquan Sun a,\# \\ a Dalian National Laboratory for Clean Energy, Dalian Institute of Chemical Physics, Chinese Academy of Sciences, Dalian 116023, Liaoning, China \\ b University of Chinese Academy of Sciences, Beijing 100049, China
}

\section{A R T I C L E I N F 0}

Article history:

Received 23 April 2016

Accepted 23 May 2016

Published 5 July 2016

Keywords:

Platinum

Phosphoric anion poisoning

Oxygen reduction reaction

Modified electrode

$\mathrm{H}_{3} \mathrm{PO}_{4}$-PBI based fuel cells

\section{A B S T R A C T}

Nafion-membrane-based proton exchange fuel cells (PEMFCs) typically operate at below $100{ }^{\circ} \mathrm{C}$. However, $\mathrm{H}_{3} \mathrm{PO}_{4}$-doped polybenzimidazole (PBI)-based PEMFCs can operate at $100-200{ }^{\circ} \mathrm{C}$. This is advantageous because of accelerated reaction rates and enhanced tolerance to poisons such as $\mathrm{CO}$ and $\mathrm{SO}_{2}$, which can arise from reformed gas or the atmosphere. However, the strong adsorption of phosphoric anions on the Pt surface dramatically decreases the electrocatalytic activity. This study exploits the "third-body effect", in which a small amount of organic molecules are pre-adsorbed on the Pt surface to inhibit the adsorption of phosphoric anions. Pre-adsorbate species inhibit the adsorption of phosphoric anions, but can also partially occlude active sites. Thus, the optimum pre-adsorbate coverage is studied by correlating the oxygen reduction reaction (ORR) activity of Pt with pre-adsorbate coverage on the Pt surface. The influence of the pre-adsorbate molecule length is investigated using the organic amines, butylamine, octylamine, and dodecylamine, in both 0.1 $\mathrm{mol} / \mathrm{L} \mathrm{HClO}_{4}$ and $0.1 \mathrm{~mol} / \mathrm{L} \mathrm{H}_{3} \mathrm{PO}_{4}$. Such amines readily bond to the Pt surface. In aqueous $\mathrm{HClO}_{4}$ electrolyte, the ORR activity of Pt decreases monotonically with increasing pre-adsorbate coverage. In aqueous $\mathrm{H}_{3} \mathrm{PO}_{4}$ electrolyte, the ORR activity of Pt initially increases and then decreases with increasing pre-adsorbate coverage. The maximum ORR activity in $\mathrm{H}_{3} \mathrm{PO}_{4}$ occurs at a pre-adsorbate coverage of around $20 \%$. The effect of molecular length of the pre-adsorbate is negligible, but its coverage strongly affects the degree to which phosphoric anion adsorption is inhibited. Butylamine adsorbs to Pt at partial active sites, which decreases the electrochemically active surface area. Adsorbed butylamine may also modify the electronic structure of the Pt surface. The ORR activity in the phosphoric acid electrolyte remains relatively low, even when using the pre-adsorbate modified $\mathrm{Pt} / \mathrm{C}$ catalysts. Further development of the catalyst and electrolyte is required before the commercialization of $\mathrm{H}_{3} \mathrm{PO}_{4}$-PBI-based PEMFCs can be realized.

(C) 2016, Dalian Institute of Chemical Physics, Chinese Academy of Sciences. Published by Elsevier B.V. All rights reserved.

\section{Introduction}

Nafion-membrane-based proton exchange fuel cells (PEM-
FCs) typically operate at below $100{ }^{\circ} \mathrm{C}$. However, $\mathrm{H}_{3} \mathrm{PO}_{4}$-doped polybenzimidazole (PBI)-based PEMFCs can operate at 100-200 ${ }^{\circ} \mathrm{C}$, so are known as high-temperature PEMFCs

\footnotetext{
* Corresponding author. Tel: +86-411-84379603; E-mail: sunshine@dicp.ac.cn

\# Corresponding author. Tel: +86-411-84379063; E-mail: gqsun@dicp.ac.cn

This work is supported by the Strategic Priority Research Program of the Chinese Academy of Sciences (XDA09030104), the National Basic Research Program of China (973 Program, 2012CB215500), and the Key Program of the Chinese Academy of Sciences (KGZD-EW-T08).

DOI: 10.1016/S1872-2067(16)62472-5 | http://www.sciencedirect.com/science/journal/18722067 | Chin. J. Catal., Vol. 37, No. 7, July 2016
} 
(HT-PEMFCs). This is advantageous because of accelerated reaction rates and enhanced tolerance to poisons such as CO and $\mathrm{SO}_{2}$, which can arise from reformed gas or the atmosphere. The higher operation temperature also simplifies water management of the single phase. HT-PEMFCs are highly efficient and environmentally benign power generators, so have extensive application prospects in power stations and potable power sources [1]. Phosphoric acid-doped PBI is a "state-of-the-art" electrolyte in HT-PEMFCs as it possesses high conductivity and superior stability at temperatures as high as $200{ }^{\circ} \mathrm{C}[2-6]$. $\mathrm{H}_{3} \mathrm{PO}_{4}$ is doped into the PBI and also added to the catalyst layer to facilitate proton transfer. Unfortunately, $\mathrm{H}_{3} \mathrm{PO}_{4}$ also tends to adsorb on the Pt surface, which occludes Pt active sites and degrades its catalytic activity [7]. There is an $~ 38-93-\mathrm{mV}$ loss in the half-wave potential of the cathodic oxygen reduction reaction (ORR) of $\mathrm{Pt}$ in the presence of $\mathrm{H}_{3} \mathrm{PO}_{4}$ compared with that in pure $\mathrm{HClO}_{4}$ electrolyte. The exact loss depends on the dominant exposed facet of the $\mathrm{Pt}$, and occurs at $\mathrm{H}_{3} \mathrm{PO}_{4}$ concentrations as low as $1 \mathrm{mmol} / \mathrm{L}$ [8].

In the past, phosphoric anion adsorption on the Pt surface has attempted to be mitigated by modifying the electronic structure [9] or tuning the geometric configuration of Pt [10]. Pt alloys such as PtNi and PtCo exhibit a d-band center that is down-shifted compared with that of Pt. This down-shift results in weaker adsorption of phosphoric anions and hydroxide anions [11]. The situation is different for PtAu alloys, in which the d-band center of the Pt is up-shifted. Nevertheless, better ORR activity of PtAu was observed in $\mathrm{H}_{3} \mathrm{PO}_{4}$ electrolyte compared with $\mathrm{Pt}$. This was explained by the geometric effect, where phosphoric anions preferentially adsorb at "three-fold sites" on the Pt surface $[8,12,13]$. The presence of such sites is lower on the PtAu alloy surface because Pt atoms are isolated by $\mathrm{Au}$ atoms [14].

Another strategy was recently proposed to suppress phosphoric anion adsorption. This involves pre-adsorbing $\mathrm{CN}^{-}$and other molecules on the Pt surface. This decreases the availability of three-fold sites on the Pt surface and thus suppresses phosphoric anion adsorption. This has been referred to as the "third-body effect" [15,16]. Pre-adsorbates suppress the adsorption of phosphoric anions, but sacrifice partial Pt active sites. Thus, the catalytic activity of Pt depends on the pre-adsorbate coverage. Markovic et al. [17] investigated poisoning of the $\operatorname{Pt}(111)$ surface by sulfuric anions, and correlated the pre-adsorbate surface coverage $\left(\Theta_{\mathrm{CNad}}\right)$ with the ORR activity in $0.05 \mathrm{~mol} / \mathrm{L} \mathrm{H}_{2} \mathrm{SO}_{4}$. A small change in $\Theta_{\mathrm{cNad}}$ had a dramatic effect on the ORR activity and peroxide production. When the electronic and ensemble effects of adsorbed spectators were balanced, the ORR activity exhibited a bell-shaped dependence on coverage, at a $\Theta_{\mathrm{CNad}}$ of $0.3 \mathrm{ML}$ (atomic monolayer). As well as acting as a third body, electron-donating pre-adsorbates reportedly modify the electronic structure of Pt in Pt alloys, thus improving the catalytic activity [9,18-21].

Amine functional groups readily bond with Pt and their $\mathrm{N}$ atoms can potentially donate electrons to transition metals [9,22-24]. In the current study, butylamine (BA) is used as a pre-adsorbate. The influence of BA coverage on the ORR activity of a smooth Pt bulk electrode is investigated in $0.1 \mathrm{~mol} / \mathrm{L}$
$\mathrm{HClO}_{4}$ and $0.1 \mathrm{~mol} / \mathrm{L} \mathrm{H}_{3} \mathrm{PO}_{4}$. The influence of the length of the pre-adsorbate molecule on the ORR activity of a Pt/C catalyst is then investigated in $0.1 \mathrm{~mol} / \mathrm{L} \mathrm{HClO}_{4}$ and $0.1 \mathrm{~mol} / \mathrm{L} \mathrm{H}_{3} \mathrm{PO}_{4}$. A series of organic amines, BA, octylamine (OA), and dodecylamine (DA) is used for this purpose.

\section{Experimental}

\subsection{Preparation of working electrode}

\subsubsection{Modification of the smooth Pt bulk electrode}

Before modification, the Pt bulk electrode (diameter of 5 $\mathrm{mm}$, geometric surface area of $0.196 \mathrm{~cm}^{2}$ ) was polished using $50 \mathrm{~nm} \mathrm{Al} \mathrm{O}_{3}$ paste, and then cleaned consecutively in concentrated sulfuric acid and sodium hydroxide. Two $\mu \mathrm{L}$ of BA solution $(0.01 \mathrm{mmol} / \mathrm{L}$ in ethanol) was pipetted onto the Pt surface. Evaporation of the ethanol yielded the BA-modified Pt bulk electrode.

\subsubsection{Modification of the Pt/C catalyst}

Fifty mg of Pt/C catalyst (Johnson Matthey, HISPECTM4000, $40 \mathrm{wt} \% \mathrm{Pt}$ ) was wetted by distilled water, and then dispersed in ethanol to form a uniform ink of concentration of $1 \mathrm{mg} / \mathrm{mL}$. Four $\mu \mathrm{L}$ of BA was then dissolved in ethanol, and was added dropwise to the catalyst ink under ultrasonication. The ink was then filtered, washed with ethanol, and dried under vacuum. The obtained sample was denoted as BA-Pt/C. Replacing BA with $\mathrm{OA}$ or DA yielded $\mathrm{OA}-\mathrm{Pt} / \mathrm{C}$ and $\mathrm{DA}-\mathrm{Pt} / \mathrm{C}$, respectively.

\subsubsection{Preparation of the thin film electrode}

The preparation of the thin film electrode is described elsewhere $[25,26]$. Briefly, the catalyst powder was dispersed in a water $/ 5 \mathrm{wt} \%$ Nafion-ionomer/ethanol solution (1:1:100, $v / v / v$ ), to form a uniform ink of concentration of $2.5 \mathrm{mg} / \mathrm{mL}$. A glassy carbon rotating disc electrode (diameter of $5 \mathrm{~mm}$, geometric surface area of $0.196 \mathrm{~cm}^{2}$ ) was polished and cleaned. Ten $\mu \mathrm{L}$ of ink was then pipetted on the glassy carbon electrode and allowed to dry, to form a thin uniform catalyst film. The Pt loading on the working electrode was $25 \mu \mathrm{g} / \mathrm{cm}^{2}$.

\subsection{Determination of BA coverage on Pt bulk surface, and measurements of ORR activity}

\subsubsection{Electrochemical apparatus}

Electrochemical measurements were conducted on a CHI 760B instrument, using a typical three-electrode cell, with a Pt wire as a counter electrode and saturated calomel electrode (SCE, $0.302 \mathrm{~V}$ vs. reversible hydrogen electrode (RHE) in 0.1 mol/L $\mathrm{HClO}_{4}, 0.327 \mathrm{~V}$ vs. RHE in $0.1 \mathrm{~mol} / \mathrm{L} \mathrm{H}_{3} \mathrm{PO}_{4}$ ) as a reference electrode. A salt bridge was used to prevent contamination of the electrolyte and $\mathrm{Pt}$ catalyst by $\mathrm{Cl}^{-}$. All potentials stated in this study have been converted into potentials vs. RHE.

\subsubsection{Determination of BA coverage on Pt surface}

The modified Pt bulk electrode was first electrochemically cleaned in $\mathrm{N}_{2}$-saturated $0.1 \mathrm{~mol} / \mathrm{L} \mathrm{HClO}_{4}$ by cycling in the potential window $0.05-1.05 \mathrm{~V}$ (a safe window for BA) at a scan 
rate of $100 \mathrm{mV} / \mathrm{s}$. This removed ethanol and other contaminants. BA molecules gradually desorbed or were electrochemically oxidized when the potential was higher than $+1.1 \mathrm{~V}$. After cleaning, the electrode was experienced potential scanning from 0.05 to $1.1 \mathrm{~V}$ to desorb BA molecules gradually by increasing the sweep cycles. The BA coverage was determined by comparing the charge of the underpotential adsorption-desorption of atomic hydrogen $\left(Q_{\mathrm{H}}\right)$ in the potential window of $0.05-0.42 \mathrm{~V}$ in the background cyclic voltammetry (CV) curve of the modified Pt bulk electrode with that of a clean Pt bulk electrode. A constant of $0.21 \mathrm{mC} / \mathrm{cm}^{2} \mathrm{Pt}\left(\Theta_{\mathrm{BA}}=Q_{\mathrm{H}} / Q^{0} \mathrm{H}\right)$ was assumed.

\subsubsection{Measurement of ORR activity}

Electrodes were first electrochemically cleaned in $\mathrm{N}_{2}$-saturated $0.1 \mathrm{~mol} / \mathrm{L} \mathrm{HClO}_{4}$ by cycling from 0.05 to $1.05 \mathrm{~V}$ at a scan rate of $100 \mathrm{mV} / \mathrm{s}$. Background CV curves and ORR polarization curves were collected at a scan rate of $10 \mathrm{mV} / \mathrm{s}$ in $\mathrm{N}_{2}$-saturated $0.1 \mathrm{~mol} / \mathrm{L} \mathrm{HClO}_{4}$ (statistic), $\mathrm{O}_{2}$-saturated 0.1 $\mathrm{mol} / \mathrm{L} \mathrm{HClO}_{4}$, and $0.1 \mathrm{~mol} / \mathrm{L} \mathrm{H}_{3} \mathrm{PO}_{4}$, at a rotation rate of 1600 $\mathrm{r} / \mathrm{min}$. The specific activity was evaluated from the kinetic current at $0.9 \mathrm{~V}$ vs. RHE, using the Koutecky-Levich equation:

$$
1 / i=1 / i_{k}+1 / i_{\text {lim }}
$$

where $i$ and $i_{\text {lim }}$ are the measured ORR current at $0.9 \mathrm{~V}$ and limiting current collected at $0.4 \mathrm{~V}$, respectively, in ORR polarization curves.

\section{Results and discussion}

\subsection{CV curves and ORR polarization curves over the smooth Pt surface in $\mathrm{HClO}_{4}$ and $\mathrm{H}_{3} \mathrm{PO}_{4}$ electrolytes}

CV curves and ORR polarization curves were recorded over the smooth Pt surface in $\mathrm{HClO}_{4}$ and $\mathrm{H}_{3} \mathrm{PO}_{4}$ electrolytes, and are shown in Fig. 1. The CV curves of the smooth Pt surface (Fig. 1(a)) in both electrolytes can be divided into three regions: the underpotential adsorption-desorption of hydrogen region (0.05-0.4 V vs. RHE), double-layer region (0.4-0.6 V vs. RHE), and Pt oxidation region (0.6-1.05 V vs. RHE). The most significant difference in the $\mathrm{CV}$ curve recorded in $\mathrm{H}_{3} \mathrm{PO}_{4}$ compared with that recorded in $\mathrm{HClO}_{4}$ occurs in the underpotential ad-

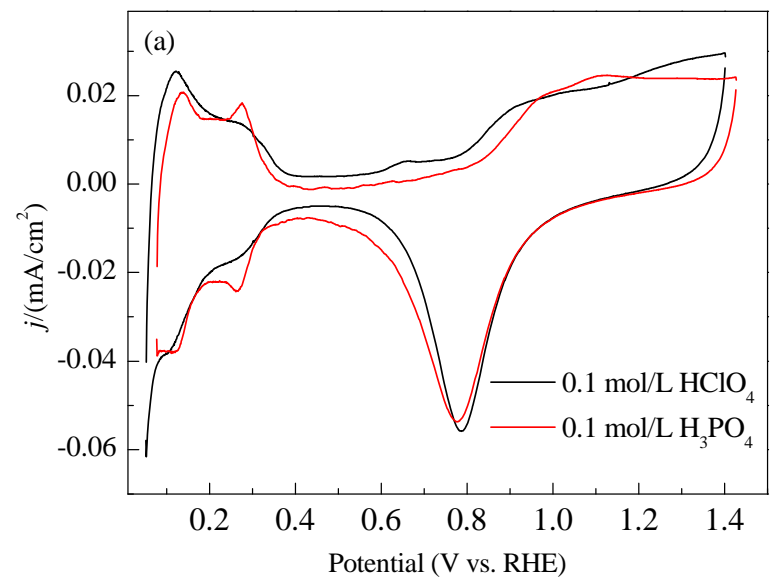

Table 1

Comparison of integrated $\mathrm{H}_{\mathrm{ad} / \mathrm{de}}$ charges $\left(Q_{\mathrm{Hupd}}\right)$, ORR onset potentials $\left(E_{0}\right)$, half-wave potentials $\left(E_{1 / 2}\right)$, and kinetic current densities at $0.9 \mathrm{~V}$ $\left(\mathrm{j}_{\mathrm{k}}{ }^{@ 0.9 v}\right)$ normalized to the geometric surface area of the electrode over the smooth Pt surface in $0.1 \mathrm{~mol} / \mathrm{L} \mathrm{HClO}_{4}$ and $0.1 \mathrm{~mol} / \mathrm{L} \mathrm{H}_{3} \mathrm{PO}_{4}$.

\begin{tabular}{lcccc}
\hline Solution & $\begin{array}{c}Q_{\mathrm{H}} \\
(\mu \mathrm{C})\end{array}$ & $\begin{array}{c}E_{0} \\
(\mathrm{mV} \text { vs. RHE})\end{array}$ & $\begin{array}{c}E_{1 / 2} \\
(\mathrm{mV} \text { vs. RHE})\end{array}$ & $\begin{array}{c}j_{\mathrm{k}} @ 0.9 \mathrm{~V} \\
\left(\mathrm{~mA} / \mathrm{cm}^{2}\right)\end{array}$ \\
\hline $0.1 \mathrm{~mol} / \mathrm{L} \mathrm{HClO}_{4}$ & 83.5 & 1012 & 795 & 0.81 \\
$0.1 \mathrm{~mol} / \mathrm{L} \mathrm{H}_{3} \mathrm{PO}_{4}$ & 80.0 & 990 & 606 & 0.14 \\
\hline
\end{tabular}

sorption-desorption of hydrogen region. In $\mathrm{HClO}_{4}$, two distinct peaks are observed at 0.13 and $0.22-0.4 \mathrm{~V}$, which are attributed to $\mathrm{Pt}(110)$ and $\mathrm{Pt}(111)$, respectively. $\mathrm{In}_{3} \mathrm{PO}_{4}$, the peak at $0.13 \mathrm{~V}$ is weaker, while the peak at $0.27 \mathrm{~V}$ is sharper, compared with in $\mathrm{HClO}_{4}$. The sharp current peak at $0.27 \mathrm{~V}$ may result from the adsorption of phosphoric anions on the reconstructed Pt surface; i.e. at potential induced stepped faces and oriented terraces from the low index facet. This is similar to observations of $\mathrm{Au}$ surfaces $[8,27]$. The integrated charge of the hydrogen region in $\mathrm{H}_{3} \mathrm{PO}_{4}$ is therefore unreliable for determining the active surface of $\mathrm{Pt}$, although this approach is suitable for $\mathrm{Pt}$ in the $\mathrm{HClO}_{4}$ electrolyte. The potential of $\mathrm{OH}^{-}$adsorption shifts to more positive values compared with the Pt oxidation region in $\mathrm{HClO}_{4}$. This indicates suppressed adsorption of $\mathrm{OH}^{-}$species on the Pt surface and the delayed formation of platinum oxide in $\mathrm{H}_{3} \mathrm{PO}_{4}$. This is probably due to the competitive adsorption of phosphoric anions and $\mathrm{OH}^{-}$species at 0.4-0.87 $\mathrm{V}$ [13].

ORR polarization curves over the smooth Pt surface in $\mathrm{HClO}_{4}$ and $\mathrm{H}_{3} \mathrm{PO}_{4}$ electrolytes are shown in Fig. 1(b). The onset potential and half-wave potential of the ORR polarization curves of the Pt bulk surface in $\mathrm{H}_{3} \mathrm{PO}_{4}$ exhibit large shifts to more negative potentials compared with those in $\mathrm{HClO}_{4}$. The charge of hydrogen underpotential adsorption-desorption (denoted $Q_{\mathrm{H}}$ ), onset potential, half-wave potential, and geometric kinetic current density are listed in Table 1 . The ORR kinetic current density of the clean Pt bulk electrode in $\mathrm{H}_{3} \mathrm{PO}_{4}$ is $17 \%$ of that in $\mathrm{HClO}_{4}$. This confirms the poisoning of Pt by phosphoric anions [8]. The maximum ORR current in the diffusion controlled region in $\mathrm{H}_{3} \mathrm{PO}_{4}(0.9 \mathrm{~mA})$ is less than that in $\mathrm{HClO}_{4}$ (1.1 $\mathrm{mA})$ under the same rotation rate. This may partly result from the decrease in Pt active sites because of the strong ad-

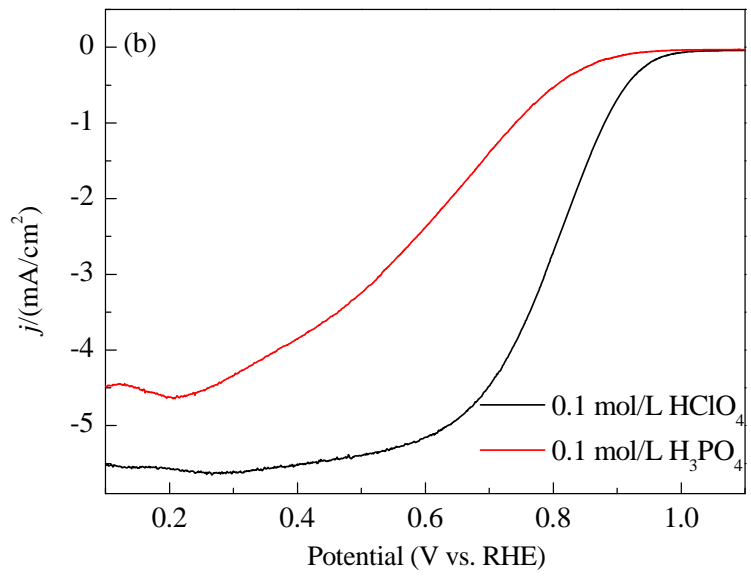

Fig. 1. CV curves (a) and ORR polarization curves (b) of clean Pt bulk electrodes in $0.1 \mathrm{~mol} / \mathrm{L} \mathrm{HClO} 4$ and $0.1 \mathrm{~mol} / \mathrm{L} \mathrm{H}_{3} \mathrm{PO}_{4}$. 
sorption of phosphoric anions, and more significantly to the $2 \mathrm{e}^{-}$ ORR pathway at $<0.3 \mathrm{~V}[17,28]$.

\subsection{Influence of BA coverage on the ORR activity of $B A$-modified Pt}

The underpotential adsorption-desorption of hydrogen regions of CV curves for the modified Pt bulk electrode with var-
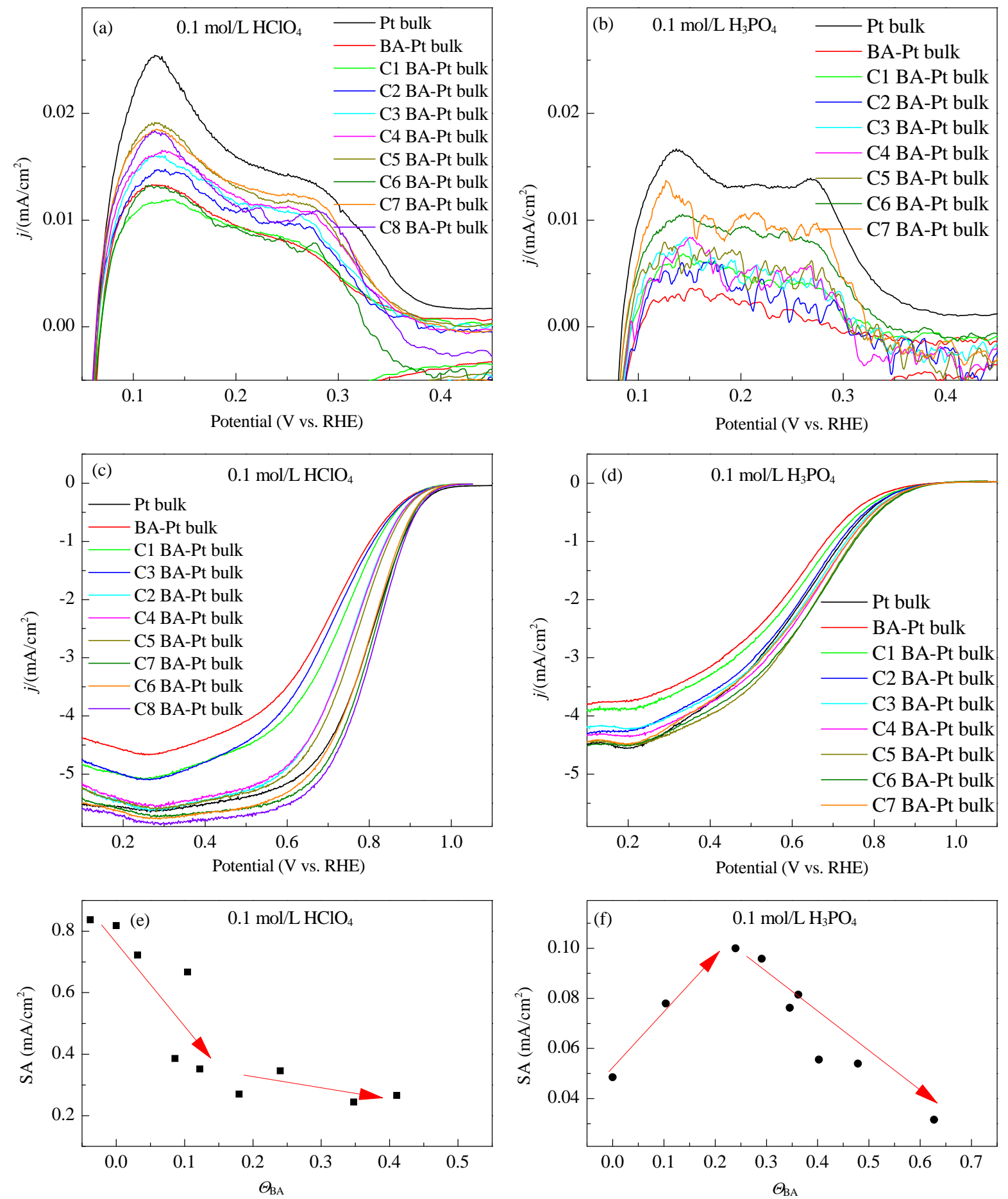

ying BA coverage is shown in Fig. 2. CV curves recorded in $\mathrm{HClO}_{4}$ and $\mathrm{H}_{3} \mathrm{PO}_{4}$ are shown in Fig. 2(a) and (b), respectively. The notation "CX BA-Pt" bulk indicates the CV curve collected after X cycles from 0.05 to $1.1 \mathrm{~V}$. From C1 BA-Pt bulk to C7 BA-Pt bulk (i.e. with increasing potential cycles as described in Section 2.2), the hydrogen underpotential adsorption-deposition current gradually increases, and peaks of the respective $\mathrm{Pt}$ crystal facet become more distinct. This is evidence for the con-

Fig. 2. CV curves (a, b), ORR polarization curves (c, d), and geometric specific activity (kinetic current density at 0.9 V) (e, f) of bulk Pt with varying coverages of BA, in $0.1 \mathrm{~mol} / \mathrm{L} \mathrm{HClO}_{4}$ and $0.1 \mathrm{~mol} / \mathrm{L} \mathrm{H}_{3} \mathrm{PO}_{4}$. 
tinuous desorption of BA from the Pt surface, and thus the decrease in BA coverage. ORR polarization curves of the modified Pt bulk surface in $\mathrm{HClO}_{4}$ and $\mathrm{H}_{3} \mathrm{PO}_{4}$ electrolytes are shown in Fig. 2(c) and (d), respectively. The derived ORR kinetic current density at $0.9 \mathrm{~V}$ (in the mixed kinetic-diffusion controlled region) as a function of BA coverage is shown in Fig. 2(e) and (f). The ORR activity of the modified Pt bulk surface progressively decreases with increasing BA coverage in $\mathrm{HClO}_{4}$, as shown in Fig. 2(e). BA molecules inevitably occupy partial Pt active sites, which decreases the electrochemically active surface area. Adsorbed BA may also modify the electronic structure of the Pt surface. Previous studies have investigated the electronic adjustment of Pt by polyvinylpyrrolidone (PVP). N atoms of adsorbed PVP accepted electrons from the Pt atoms of particles larger than $20 \mathrm{~nm}$, or even bulk Pt. Pt atoms accepted electrons from the $\mathrm{N}$ atoms of PVP for Pt nanoparticles smaller than $7 \mathrm{~nm}$ [18]. In the current study, bulk Pt may donate electrons to BA. The electron density of the modified Pt bulk surface is likely to be lowered, and the $d$-band center shifted to more positive potential, which is detrimental to ORR activity.

In $\mathrm{H}_{3} \mathrm{PO}_{4}$ electrolyte, the Pt surface is partially covered by phosphoric anions. Pre-adsorbing BA on the Pt surface suppresses the adsorption of phosphoric anions, relative to that of unmodified Pt. Fig. 2(f) shows that the ORR activity of the smooth bulk Pt electrode exhibits a bell-shaped profile with BA coverage. The highest ORR activity is obtained at a BA coverage of $\sim 20 \%$. The specific ORR activity of the modified Pt surface is lower than that of the clean bulk Pt electrode, until the BA coverage becomes higher than $50 \%$. The bell-shaped profile in ORR activity is reasonable considering the co-adsorption of BA and phosphoric anions on the Pt surface. Phosphoric anions preferentially adsorb on the Pt surface in face-centered cubic (fcc) or fcc-inverted form, occupying three-fold sites $[8,12,13]$. BA prefers to occupy the "atop" sites of Pt [22], as shown in Fig. 3. The selective adsorption of BA decreases the availability of three-fold sites, which suppresses the adsorption of phosphoric anions. A BA coverage of $20 \%$ results in the minimum co-coverage of BA and phosphoric anions, and thus the highest ORR activity as shown in Fig. 3.

\subsection{Effect of molecular length of pre-adsorbate on suppression of phosphoric anion adsorption}

BA, OA, and DA have similar molecular structures, but dif-

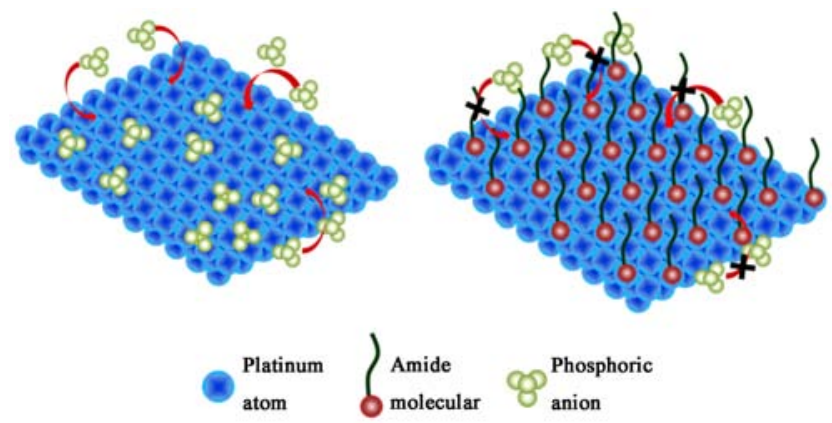

Fig. 3. Strategy to suppress the adsorption of phosphoric anions via the third-body effect. ferent chain lengths of $\sim 0.6,1.2$, and $1.8 \mathrm{~nm}$, respectively. These amines are used as pre-adsorbates to investigate the effect of molecular length on the suppression of phosphoric anion adsorption on the Pt surface, and thus on ORR activity.

Background CV curves, ORR polarization curves, and ORR-specific activities of BA-Pt/C, OA-Pt/C, and DA-Pt/C catalysts in $\mathrm{H}_{3} \mathrm{PO}_{4}$ and $\mathrm{HClO}_{4}$ electrolytes are shown in Fig. 4. Compared with pristine $\mathrm{Pt} / \mathrm{C}$, the $Q_{\mathrm{H}}$ is lower for the $\mathrm{BA}-\mathrm{Pt} / \mathrm{C}$, $\mathrm{OA}-\mathrm{Pt} / \mathrm{C}$, and DA-Pt/C catalysts in both $0.1 \mathrm{~mol} / \mathrm{L} \mathrm{HClO}_{4}$ and 0.1 mol/ $\mathrm{L} \mathrm{H}_{3} \mathrm{PO}_{4}$, as shown in Fig. 4(a) and (b), respectively. In 0.1 mol/L $\mathrm{HClO}_{4}$, with increasing pre-adsorbate length, the $Q_{\mathrm{H}}$ values are DA-Pt/C $(28.4 \mu \mathrm{C}) \approx 0 \mathrm{OA}-\mathrm{Pt} / \mathrm{C}(28.8 \mu \mathrm{C})>\mathrm{BA}-\mathrm{Pt} / \mathrm{C}(24.8$ $\mu \mathrm{C})$. In $\mathrm{H}_{3} \mathrm{PO}_{4}$, the $Q_{\mathrm{H}}$ values are BA-Pt/C $(32.1 \mu \mathrm{C})>0 A-\mathrm{Pt} / \mathrm{C}$ $(27.6 \mu \mathrm{C})>\mathrm{DA}-\mathrm{Pt} / \mathrm{C}(26.2 \mu \mathrm{C})$. $\mathrm{In}_{3} \mathrm{PO}_{4}$, the "apparent" underpotential hydrogen adsorption-desorption current contains contributions from the adsorption-desorption of hydrogen and that of phosphoric anions. Thus, the $Q_{\mathrm{H}}$ is unreliable for calculating the electrochemically active surface area in $\mathrm{H}_{3} \mathrm{PO}_{4}$, as is usually done when using $\mathrm{HClO}_{4}$.

ORR polarization curves over the modified $\mathrm{Pt} / \mathrm{C}$ electrodes in $\mathrm{HClO}_{4}$ and $\mathrm{H}_{3} \mathrm{PO}_{4}$ electrolytes, and derived Tafel plots, are shown in Fig. 4(c) and (d). For the $\mathrm{HClO}_{4}$ electrolyte, ORR currents (at $0.9 \mathrm{~V}$ ) in the Tafel plots (insets in Fig. 4(c) and (d)) are normalized to the electrochemically active surface area (ECSA) and Pt mass. For the $\mathrm{H}_{3} \mathrm{PO}_{4}$ electrolyte, they are only normalized to the Pt mass, as shown in Fig. 4(e) and (f). The ECSA cannot be calculated from the hydrogen region because of the influence by phosphoric anion adsorption on the Pt surface in $\mathrm{H}_{3} \mathrm{PO}_{4}$. In $\mathrm{HClO}_{4}$, the lower ECSA of BA/OA/DA-Pt/C due to coverage by the pre-adsorbate has little influence on the specific ORR activity. This is evidenced by their near overlapping ORR curves in Fig. 4(c), and their similar ORR-specific currents in Fig. 4(e).

The modified Pt/C catalyst exhibits better ORR activity in phosphoric acid compared with the unmodified Pt/C catalyst. This is shown in Fig. 4(d) and (f). The half-wave potential shifts by $35 \mathrm{mV}$ to more positive potential. The Pt mass-specific activities of the BA-Pt/C, OA-Pt/C, and DA-Pt/C catalysts are 1.67, 1.72 , and 1.9 -fold that of the $\mathrm{Pt} / \mathrm{C}$ catalyst, respectively. This suggests that pre-adsorbates suppress the adsorption of phosphoric anions, as is observed on the smooth Pt surface. The molecular length of the pre-adsorbate has little influence on the adsorption of phosphoric anions, in contrast to pre-adsorbate coverage. Compared with the $\mathrm{HClO}_{4}$ electrolyte, the ORR activity in the phosphoric acid electrolyte remains relatively low, even when using the pre-adsorbate-modified $\mathrm{Pt} / \mathrm{C}$ catalysts. This is because $\mathrm{HClO}_{4}$ only weakly adsorbs to Pt. Further development of the catalyst and electrolyte [7,29-31] is required to overcome phosphoric anon poisoning before the commercialization of $\mathrm{H}_{3} \mathrm{PO}_{4}$-PBI-based PEMFCs can be realized.

\section{Conclusions}

This study aimed to mitigate the poisoning of Pt by phosphoric anions using the third-body effect. This involved pre-adsorbing a small amount of organic molecules on $\mathrm{Pt}$ to inhibit the adsorption of phosphoric anions. In aqueous $\mathrm{HClO}_{4}$ 

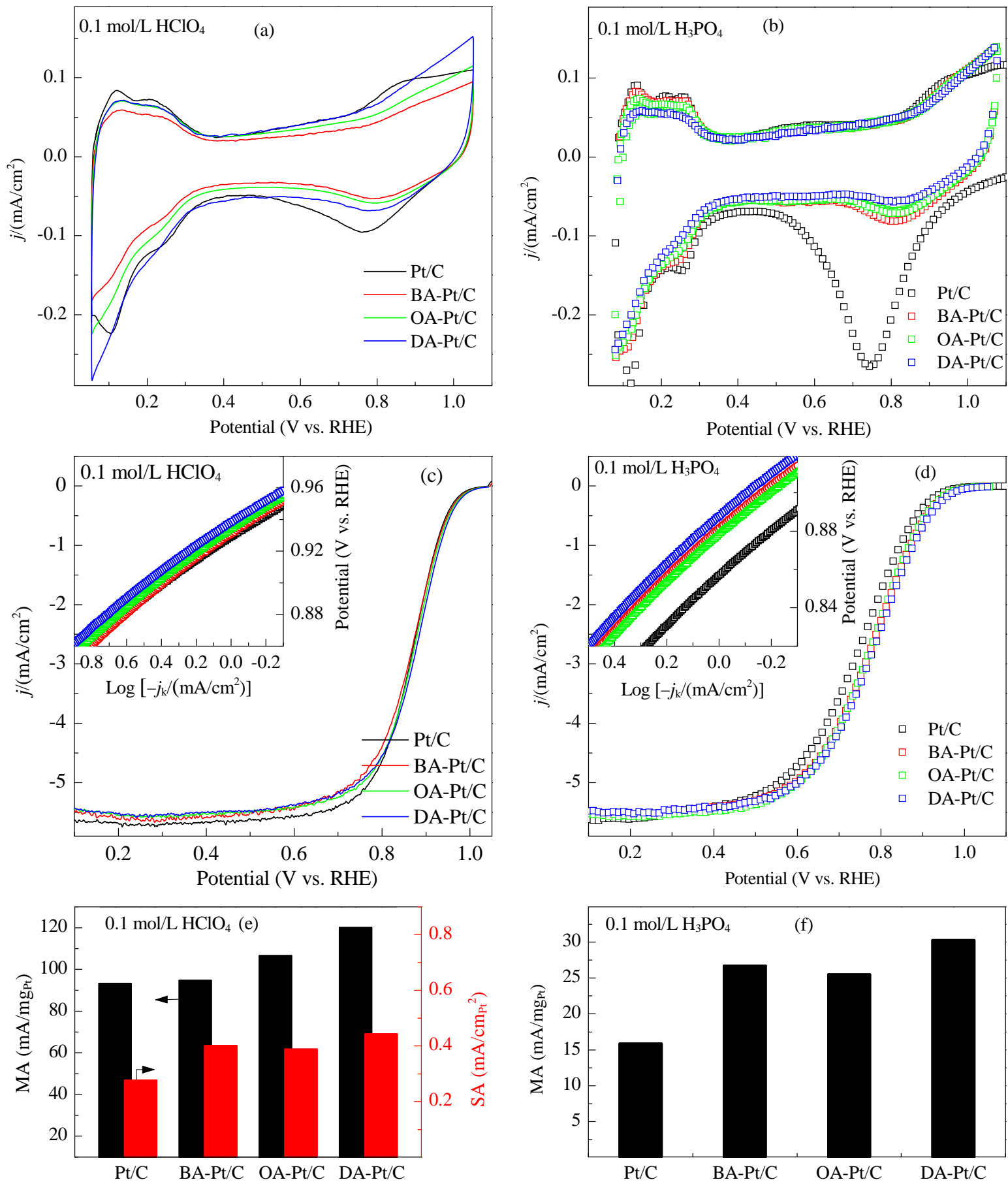

Fig. 4. CV curves (a, b), ORR polarization curves (c, d), and specific activities (kinetic current densities) at $0.9 \mathrm{~V}$ (e, f) of BA-modified, OA-modified, and DA-modified Pt/C in $0.1 \mathrm{~mol} / \mathrm{L} \mathrm{HClO}_{4}$ and $0.1 \mathrm{~mol} / \mathrm{L} \mathrm{H}_{3} \mathrm{PO}_{4}$.

electrolyte, the ORR activity of Pt decreases monotonically with increasing pre-adsorbate coverage. In aqueous $\mathrm{H}_{3} \mathrm{PO}_{4}$ electrolyte, the ORR activity of Pt initially increases and then decreases with increasing pre-adsorbate coverage, with the optimum coverage observed at $\sim 20 \%$. The molecular length of the preadsorbate has a negligible effect on the ORR activity, but its coverage strongly affects the inhibition of phosphoric anion adsorption. The ORR activity of the modified $\mathrm{Pt} / \mathrm{C}$ remains relatively low in phosphoric acid compared with in the absence of phosphoric acid. Further development is required to improve the ORR activity of Pt-based catalysts in phosphoric acid.

\section{References}

[1] Q. F. Li, R. H. He, J. O. Jensen, N. J. Bjerrum, Chem. Mater., 2003, 15, 4896-4915.

[2] Y. L. Ma, J. S. Wainright, M. H. Litt, R. F. Savinell, J. Electrochem. Soc., 2004, 151, A8-A16. 


\title{
Graphical Abstract
}

Chin. J. Catal., 2016, 37: 1134-1141 doi: 10.1016/S1872-2067(16)62472-5

Influence of phosphoric anions on oxygen reduction reaction activity of platinum, and strategies to inhibit phosphoric anion adsorption

Yuping Li, Luhua Jiang *, Suli Wang, Gongquan Sun*

Dalian Institute of Chemical Physics, Chinese Academy of Sciences; University of Chinese Academy of Sciences

Pre-adsorption of amide molecules on Pt surface effectively suppresses the phosphoric anion adsorption, resulting to a "volcanic" profile of the ORR activity as a function of the BA coverage on $\mathrm{Pt}$ surface in phosphoric acid electrolyte.

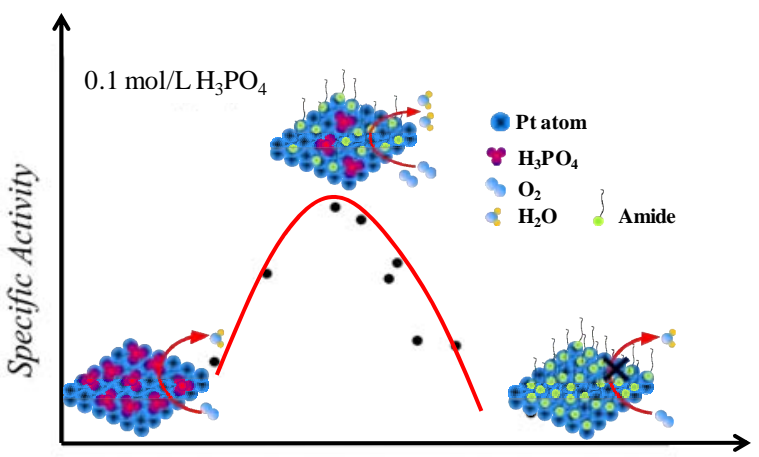

$B A$ Coverage
[3] M. Schuster, T. Rager, A. Noda, K. D. Kreuer, J. Maier, Fuel Cells, 2005, 5, 355-365.

[4] S. J. Paddison, K. D. Kreuer, J. Maier, Phys. Chem. Chem. Phys., 2006, $8,4530-4542$.

[5] H. Steininger, M. Schuster, K. D. Kreuer, A. Kaltbeitzel, B. Bingol, W. H. Meyer, S. Schauff, G. Brunklaus, J. Maier, H. W. Spiess, Phys. Chem. Chem. Phys., 2007, 9, 1764-1773.

[6] J. S. Yang, R. H. He, Q. T. Che, X. L. Gao, L. L. Shi, Polym. Int., 2010, 59, 1695-1700.

[7] P. Zelenay, B. R. Scharifker, J. O'M. Bockris, D. Gervasio, J. Electrochem. Soc., 1986, 133, 2262-2267.

[8] Q. G. He, X. F. Yang, W. Chen, S. Mukerjee, B. Koel, S. W. Chen, Phys. Chem. Chem. Phys., 2010, 12, 12544-12555.

[9] Y. H. Chung, D. Y. Chung, N. Jung, Y. E. Sung, J. Phys. Chem. Lett., 2013, 4, 1304-1309.

[10] K. S. Lee, S. J. Yoo, D. Ahn, S. K. Kim, S. J. Hwang, Y. E. Sung, H. J. Kim, E. Cho, D. Henkensmeier, T. H. Lim, J. H. Jang, Electrochim. Acta, 2011, 56, 8802-8810.

[11] Y. H. Chung, S. J. Kim, D. Y. Chung, M. J. Lee, J. H. Jang, Y. E. Sung, Phys. Chem. Chem. Phys., 2014, 16, 13726-13732.

[12] Q. G. He, B. Shyam, M. Nishijima, D. Ramaker, S. Mukerjee, J. Phys. Chem. C, 2013, 117, 4877-4887.

[13] S. Kaserer, K. M. Caldwell, D. E. Ramaker, C. Roth, J. Phys. Chem. C, 2013, 117, 6210-6217.

[14] J. E. Lim, U. J. Lee, S. H. Ahn, E. Cho, H. J. Kim, J. H. Jang, H. Son, S. K. Kim, Appl. Catal. B, 2015, 165, 495-502.

[15] D. Strmcnik, M. Escudero-Escribano, K. Kodama, V. R. Stamenkovic, A. Cuesta, N. M. Marković, Nat. Chem., 2010, 2, 880-885.

[16] H. Angerstein-Kozlowska, B. MacDougall , B. E. Conway, J. Electrochem. Soc., 1973, 120, 756-766.
[17] E. G. Ciapina, P. P. Lopes, R. Subbaraman, E. A. Ticianelli, V. Stamenkovic, D. Strmcnik, N. M. Markovic, Electrochem. Commun., 2015, 60, 30-33.

[18] L. Qiu, F. Liu, L. Zhao, W. S. Yang, J. N. Yao, Langmuir, 2006, 22, 4480-4482.

[19] Z. Y. Zhou, X. W. Kang, Y. Song, S. W. Chen, J. Phys. Chem. C, 2012, $116,10592-10598$.

[20] Z. Y. Zhou, X. W. Kang, Y. Song, S. W. Chen, Chem. Commun., 2012, 48, 3391-3393.

[21] J. E. Newton, J. A. Preece, N. V. Rees, S. L. Horswell, Phys. Chem. Chem. Phys., 2014, 16, 11435-11446.

[22] K. Miyabayashi, H. Nishihara, M. Miyake, Langmuir, 2014, 30, 2936-2942.

[23] Y. H. Chung, S. J. Kim, D. Y. Chung, H. Y. Park, Y. E. Sung, S. J. Yoo, J. H. Jang, Chem. Commun., 2015, 51, 2968-2971.

[24] J. Liu, L. H. Jiang, Q. W. Tang, E. D. Wang, L. T. Qi, S. L. Wang, G. Q. Sun, Appl. Catal. B, 2014, 148-149, 212-220.

[25] U. A. Paulus, T. J. Schmidt, H. A. Gasteiger, R. J. Behm, J. Electroanal. Chem., 2001, 495, 134-145.

[26] Y. Garsany, O. A. Baturina, K. E. Swider-Lyons, S. S. Kocha, Anal. Chem., 2010, 82, 6321-6328.

[27] F. Silva, A. Martins, Electrochim. Acta, 1998, 44, 919-929.

[28] M. D. Maciá, J. M. Campiña, E. Herrero, J. M. Feliu, J. Electroanal. Chem., 2004, 564, 141-150.

[29] M. Razaq, A. Razaq, E. Yeager, D. D. DesMarteau, S. Singh, J. Electrochem. Soc., 1989, 136, 385-390.

[30] E. Heider, N. Ignatiev, L. Jörissen, A. Wenda, R. Zeis, Electrochem. Commun., 2014, 48, 24-27.

[31] E. Heider, Z. Jusys, R. J. Behm, L. Jörissen, R. Zeis, J. Phys. Chem. $C$ 2015, 119, 18859-188.

\section{铂催化氧还原反应过程中磷酸的影响及抑制磷酸吸附策略}

\author{
李玉萍 ${ }^{\mathrm{a}, \mathrm{b}}$ ，姜鲁华 ${ }^{\mathrm{a},{ }^{*}}$ ，王素力 ${ }^{\mathrm{a}}$ ，孙公权 ${ }^{\mathrm{a}, \#}$ \\ a中国科学院大连化学物理研究所, 洁净能源国家实验室(筹), 辽宁大连 116023 \\ ${ }^{\mathrm{b}}$ 中国科学院大学, 北京 100049
}

摘要: 与低温 $\left(<100{ }^{\circ} \mathrm{C}\right)$ 质子交换膜燃料电池相比, 磷酸掺杂 $\mathrm{PBI}$ 膜燃料电池可工作于 $100-200^{\circ} \mathrm{C}$, 工作温度的提高有利于提 高电极反应动力学速率、增加 $\mathrm{Pt}$ 催化剂对 $\mathrm{CO}$ 等毒物的耐受性, 以及简化电池水管理等. 然而, 磷酸在 $\mathrm{Pt}$ 催化剂表面吸附较 强, 这将造成 $\mathrm{Pt}$ 一定程度的毒化. 基于“第三体效应”, 即在Pt表面预吸附某些小分子, 可在一定程度上抑制磷酸吸附, 然而 
预吸附分子同时也将占据Pt表面部分活性位点, 因而Pt的催化性能最终由两个因素决定：磷酸抑制程度和预吸附分子在 $\mathrm{Pt}$ 表面的覆盖度.

本文系统考察了 $\mathrm{Pt}$ 表面预吸附分子覆盖度和预吸附分子链长对其催化氧还原反应(ORR)活性的影响. 首先, 通过控制 预吸附了胺类分子的Pt电极的电位, 得到表面具有不同覆盖度的Pt电极, 考察了 $0.1 \mathrm{~mol} / \mathrm{L} \mathrm{H}_{3} \mathrm{PO}_{4}$ 电解液中Pt电极对ORR的 催化活性随预吸附分子覆盖度的变化规律; 为分离磷酸吸附和修饰分子吸附本身对 $\mathrm{Pt}$ 催化活性的影响, 对比了 $0.1 \mathrm{~mol} / \mathrm{L}$ $\mathrm{HClO}_{4}$ 电解液中Pt电极对 ORR 的催化活性随预吸附分子覆盖度的变化规律. 进一步对比研究了不同链长胺分子一一正丁 胺 $(\mathrm{BA})$ 、正辛胺 $(\mathrm{OA})$ 及十二胺 $(\mathrm{DA})$ 等作为修饰分子对 $\mathrm{Pt} / \mathrm{C}$ 催化剂电催化ORR活性的影响. 结果表明, 随修饰分子在 $\mathrm{Pt}$ 表面 覆盖度提高, 在 $0.1 \mathrm{~mol} / \mathrm{L} \mathrm{HClO}_{4}$ 溶液中, 由于预吸附分子占据Pt部分活性位, 修饰后光滑Pt电极表面的本征活性单调下降; 而在 $0.1 \mathrm{~mol} / \mathrm{L} \mathrm{H}_{3} \mathrm{PO}_{4}$ 中, 修饰后光滑Pt电极表面的ORR活性呈现先升高后降低的趋势, 当预吸附分子覆盖度约为 $20 \%$ 时, 其 ORR活性最高, 为未修饰的光滑Pt电极表面的1.67倍. 这表明预吸附分子有效抑制了磷酸的吸附, 且当预吸附分子覆盖度 约为 $20 \%$ 时, 预吸附分子对Pt表面的占据与其抑制磷酸吸附的作用达到最佳平衡点. 然而, 当修饰分子 BA, OA和DA在Pt表 面覆盖度分别为 $38.6 \%, 26.1 \%$ 和 $26.1 \%$ 时, Pt/C在 $0.1 \mathrm{~mol} / \mathrm{L} \mathrm{H}_{3} \mathrm{PO}_{4}$ 中的ORR催化活性接近, 分别为未经修饰Pt/C电催化剂的 1.7, 1.8和2.0倍, 这表明预吸附分子链长对ORR催化活性影响较小, 表面预吸附分子抑制磷酸吸附的策略对 Pt/C催化剂也同 样适用. 同时, $\mathrm{Pt} / \mathrm{C}$ 电极经BA, OA和DA修饰后, 其在 $0.1 \mathrm{~mol} / \mathrm{L} \mathrm{HClO}_{4}$ 中的比表面活性分别为未经修饰Pt/C电催化剂的1.0, 1.1 和1.3倍, 与修饰后光滑Pt电极表面本征ORR活性变化规律不一致. 然而, 与 $\mathrm{Pt}$ 在 $\mathrm{HClO}_{4}$ 电解质中的ORR活性相比, ORR 的半波电位仍有大约 $123 \mathrm{mV}$ 的差距, 今后还需继续从催化剂的角度, 如调控Pt表面的吸附特性, 或从创新电解质的角度, 如 有机磷酸电解质等出发解决磷酸毒化的问题.

关键词: 铂; 磷酸毒化; 氧还原反应; 修饰电极; 磷酸掺杂PBI膜燃料电池

收稿日期: 2016-04-23. 接受日期: 2016-05-23. 出版日期: 2016-07-05.

*通讯联系人. 电话: (0411)84379603; 电子信箱: sunshine@dicp.ac.cn

通讯联系人. 电话: (0411)84379063; 电子信箱: gqsun@dicp.ac.cn

基金来源: 中国科学院战略先导专项(XDA09030104); 国家重点基础研究发展计划(973计划, 2012CB215500); 中国科学院重点 项目(KGZD-EW-T08).

本文的英文电子版由Elsevier出版社在ScienceDirect上出版(http://www.sciencedirect.com/science/journal/18722067). 